Article

\title{
Climate Change and Fisheries Regulation: What We Should Consider for the Future?
}

Keyuan Zou (D)

check for

updates

Citation: Zou, K. Climate Change and Fisheries Regulation: What We Should Consider for the Future?. Sustainability 2021, 13, 9735. https:// doi.org/10.3390/su13179735

Academic Editor: Tim Gray

Received: 21 June 2021

Accepted: 18 August 2021

Published: 30 August 2021

Publisher's Note: MDPI stays neutral with regard to jurisdictional claims in published maps and institutional affiliations.

Copyright: (C) 2021 by the author. Licensee MDPI, Basel, Switzerland. This article is an open access article distributed under the terms and conditions of the Creative Commons Attribution (CC BY) license (https:// creativecommons.org/licenses/by/ $4.0 /)$.
School of Law, Dalian Maritime University, Dalian 116000, China; zoukeyuan@dlmu.edu.cn

\begin{abstract}
Climate change and its effect on marine environment, especially ocean warming, acidification and sea level rise, impacts fisheries in different ways. However, fisheries and climate change are regulated by different international management mechanisms, which makes the current fisheries management system face challenges. Realizing this, the present paper is designed to consider whether international law should be introduced to apply better management of fisheries so as to cope with the issues arising from climate change. In addition, the paper highlights the importance of incorporating relevant principles into future fisheries regulations by examining an existing bilateral fishery agreements.
\end{abstract}

Keywords: climate change; fishery management; legal principles; LOSC; precautionary approach; sustainable development; ecosystem

\section{Introduction}

It is acknowledged that the precise and localized impacts of climate change on fisheries are still poorly understood [1]. This is because "the inherent unpredictability of climate change and the links that entwine fishery and aquaculture livelihoods with other livelihood strategies and economic sectors make unravelling the exact mechanisms of climate impacts hugely complex" [2]. This view is agreed to by the Stern Review on the Economics of Climate Change, in its statement that "for fisheries, information on the likely impacts of climate change is very limited" [3]. The ocean has absorbed $93 \%$ of the extra heat arising from the enhanced greenhouse effect (1971-2010), with most of the warming (64\%) occurring in the upper $(0$ to $700 \mathrm{~m})$ ocean [4]. To reverse that heating, the warmer upper layers of the ocean have to mix with the colder, deeper layers, which can take as much as 1000 years [4]. Temperature plays an essential role in the biology and ecology of marine organisms, the speed of isotherm migration ultimately determines the speed at which populations must move, adapt or acclimate to changed sea temperatures [4]. Shifts in stock distribution due to climate change have the potential of creating local extinction of economically important stocks while enhancing fisheries in areas where they were not present before [5]. For example, since 2010, the distribution proportion of Pacific halibut has increased from $9 \%$ to $11 \%$ in Canadian waters, and from $7.5 \%$ to $13 \%$ in Alaskan waters [5].

Oceans also absorb approximately $30 \%$ of emitted anthropogenic $\mathrm{CO}_{2}$, causing ocean acidification [6]. Rising water temperatures and ocean acidification damage coral reefs by enhancing reef dissolution and bio-erosion, affecting coral species distribution, and leading to community changes. Coral reefs are further exposed to other increased impacts, such as enhanced storm intensity, turbidity and increased runoff from the land [6]. Relatively small increases in sea temperature (as little as $1^{\circ} \mathrm{C}$ to $2{ }^{\circ} \mathrm{C}$ ) can cause mass coral bleaching and mortality across hundreds of square kilometers of coral reef [4]. When this occurs on a global scale, it is referred to as a "mass bleaching event." In 1998 a mass bleaching event killed almost $16 \%$ of the world's reef-building corals [7]. Loss of coral reef habitats leads to a reduction in reef fisheries production, which negatively impacts communities and countries highly dependent on coral reef ecosystems for their food, income and livelihoods. The economic costs due to the ocean acidification-driven reduction in the fisheries production 
of coral reef habitats are estimated to be between $\$ 5.4$ to $\$ 8.4$ billion annually under a high emission scenario [8]. What is worse is that ocean acidification can slow the rebuilding of coral reefs and weaken their structures.

The links between fisheries and their ecosystems are deeper and more significant than those that exist in mainstream agriculture [9]. The productivity of a fishery is tied to the health and functioning of the ecosystems on which it depends for food, habitat and even seed dispersal [10]. Estuaries, mangroves, coral reefs and seagrass beds are particularly significant in the provision of ecosystem services, especially as nurseries for young fish, and are also amongst the most sensitive and highly exposed to the negative impacts of coastal development, pollution, sedimentation, destructive fishing practices, and climate change [7]. Because fish tend to live near their tolerance limits of a range of factors, increased temperature and acidity, lower dissolved oxygen, and changes to salinity can have deleterious effects [11].

Sea level rise will likely damage or destroy many coastal ecosystems such as mangroves, seagrasses, and coral reefs, which are essential to maintaining wild fish stocks [12]. The threats to coastal habitats and fisheries from sea-level rise are exacerbated by increases in coastal extreme events, such as tropical cyclone winds and rainfall [12]. Changes in surface temperature could alter local ecosystems and affect the abundance and species composition of fish stocks [2].

Climate change in particular would affect fisheries and the fishery industry in East Asia. As we know, $85 \%$ of fishers and fish farmers worldwide live in Asia, with the greatest numbers being in China (9.6 million fishers and 5.0 million fish farmers) [13]. China is the largest producer of fish, accounting for 35 percent of global fish production in 2018 [14]. Thus, any adverse impact of climate change on fisheries will inevitably affect the livelihoods of fishers and fishing communities, particularly in Asia.

It is evident that climate change has impact on fishery, the present paper is designed to consider whether international law, particularly international legal principles, should be introduced to apply better management to fisheries so as to cope with the issues arising from climate change.

\section{Applicability of Legal Principles}

As for the legal governance of climate change and fisheries, there are two different but associated legal frameworks in international law. The former is regulated by the United Nations Framework Convention on Climate Change (UNFCCC) while the latter is regulated by the United Nations Convention on the Law of the Sea (LOSC). Though governed by two different legal regimes, the two sets of laws have some legal principles in common. It is acknowledged that although there are no specific references to climate change in most of the Law of the Sea instruments, there are rules relevant to climate change both under the LOSC and under customary law in this field [15,16]. In most recent marine pollution instruments, specific references to climate change remain relatively rare [15]. One example which incorporates climate change is the 2008 Protocol on Integrated Coastal Zone Management in the Mediterranean Sea. It makes express reference to the UNFCCC and to climate change in preambular paragraphs, and in Article 5 (e) it identifies the obligation of States parties to "prevent and/or reduce the effects in particular of climate change," as one of the objectives of integrated coastal management [15]. However, there is no such express mention in fisheries agreements, whether global, regional, or bilateral. Yet the following legal principles should be applicable to both climate change and fishery management.

\subsection{Precautionary Approach/Principle}

This principle/approach requires states to take precautionary measures even if there is no conclusive scientific proof of potential damage to a particular natural environment, climate, or fishery. The precautionary approach was first incorporated into the international fisheries law as the 1995 Straddling Fish Stocks Agreement provides that "States shall apply the precautionary approach widely to conservation, management and exploitation of 
straddling fish stocks and highly migratory fish stocks in order to protect the living marine resources and preserve the marine environment." In order to implement this approach, states shall, e.g., improve decision-making for fishery resource conservation, obtain and share the best scientific information; take into account, inter alia, uncertainties relating to the size and productivity of the stocks, reference points, and stock condition; and develop data collection and research programs to assess the impact of fishing on non-targets [17].

The Seabed Chamber of the International Tribunal for the Law of the Sea (ITLOS), in its 2011 Advisory Opinion on the Responsibilities and Obligations of States, confirmed that the precautionary approach is "an integral part of due diligence obligation of sponsoring States, which is applicable even outside the scope of the [Nodules and Sulphides] Regulations" [18]. This statement from an international judicial agency has no doubt strengthened the applicability of the precautionary approach not only to deep seabed activities, but also to other ocean uses, including fisheries.

In state practice, the North Pacific Fishery Management Council (NPFMC) has closed sections of the ocean to fishing because of the scientific uncertainty of data due to climate change, and the Arctic Management Area is closed to commercial fishing until such time in the future that sufficient information is available with which to initiate a planning process for commercial fishery development [19].

This principle/approach is also applicable to climate change when there is a reasonable, foreseeable threat of serious or irreversible damage, including serious or irreversible damage to states vulnerable to the impacts of climate change [15]. According to the UNFCCC, "The Parties should take precautionary measures to anticipate, prevent or minimize the causes of climate change and mitigate its adverse effects. Where there are threats of serious or irreversible damage, lack of full scientific certainty should not be used as a reason for postponing such measures, taking into account that policies and measures to deal with climate change should be cost-effective so as to ensure global benefits at the lowest possible cost. To achieve this, such policies and measures should take into account different socio-economic contexts, be comprehensive, cover all relevant sources, sinks and reservoirs of greenhouse gases and adaptation, and comprise all economic sectors. Efforts to address climate change may be carried out cooperatively by interested Parties" [20]. It is obvious that the precautionary approach applies to both climate change and fisheries so that there is no difficulty in incorporating it in a legal document for fishery management in coping with climate change.

\subsection{Principle of Sustainable Development}

Sustainable development means development as meets the needs of the present without compromising the ability of future generations to meet their own needs [21]. The concept has been widely accepted by the entire world community, and has gradually been reflected in national and international laws and policies, such as the 1992 Rio Declaration [22], Agenda 21 [23], and the Johannesburg Declaration [24]. One of the major purposes of the concept of sustainable development is to coordinate the relationship between resource uses and environmental protection, such that are not contradictory, nor in conflict, but can interplay mutually. Environmental protection is necessary to achieve the goal of resource uses which are sustainable, and economic benefits deriving from resources can provide the conditions in which environmental protection can best be achieved.

In international jurisprudence, the International Court of Justice has recognized the importance of sustainable development. It has developed legal doctrines concerning sustainable development particularly in two particular cases. In the case concerning the Gabčíkovo-Nagymaros Project (Hungary/Slovakia) (1993-1997), the Court held that "in the field of environmental protection, vigilance and prevention are required on account of the often irreversible character of damage to the environment and of the limitations inherent in the very mechanism of reparation of this type of damage. Throughout the ages, mankind has, for economic and other reasons, constantly interfered with nature. This need 
to reconcile economic development with protection of the environment is aptly expressed in the concept of sustainable development" [25].

In the case concerning Pulp Mills on the River Uruguay (Argentina vs. Uruguay) (2006-2010), the Court considered that "the attainment of optimum and rational utilization requires a balance between the Parties' rights and needs to use the river for economic and commercial activities on the one hand, and the obligation to protect it from any damage to the environment that may be caused by such activities, on the other" [26]. That balance is exactly a reflection of sustainable development. In the discussion on Article 27 of the Statute of the River Uruguay of 1975, the Court held that "Article 27 embodies this interconnectedness between equitable and reasonable utilization of a shared resource and the balance between economic development and environmental protection that is the essence of sustainable development" [26].

In a word, sustainability has penetrated into our daily life. Sustainable development is an indispensable requirement for ocean governance, including fishery management. In the context of the ever-deteriorating conditions of the environment we rely upon, global warming, and climate change, this application is even more important.

The climate system is a common natural resource for the benefit of present and future generations, and sustainable development requires states to balance economic and social development with the protection of the climate system, and supports the realization of the right of all human beings to an adequate living standard and equitable distribution of the benefits thereof [15]. The UNFCCC sets forth its objective as "to achieve, in accordance with the relevant provisions of the Convention, stabilization of greenhouse gas concentrations in the atmosphere at a level that would prevent dangerous anthropogenic interference with the climate system. Such a level should be achieved within a time frame sufficient to allow ecosystems to adapt naturally to climate change, to ensure that food production is not threatened and to enable economic development to proceed in a sustainable manner" [20]. In order to fulfil this objective, the Convention obliges states to "promote sustainable management, and promote and cooperate in the conservation and enhancement, as appropriate, of sinks and reservoirs including biomass, forests and oceans as well as other terrestrial, coastal and marine ecosystems" [20]. Likewise, the UN Convention on Biological Diversity, which is more relevant to fishery management, is also designed to protect the environment and promote sustainability, with the objective being to conserve biological diversity and use its components sustainably [27].

\subsection{Ecosystem Approach}

As we know, the Convention on the Conservation of Antarctic Marine Living Resources (CCAMLR) endorsed the ecosystem approach to the management of the entire Southern Ocean. This approach is in contrast to other conventions on fisheries such as the IWC, Northwest Atlantic Fisheries Organization (NAFO), or International Commission for South East Atlantic Fisheries (ICSEAF), where the aim of the convention is a sustainable yield of the target species and the welfare of the industry dependent upon it [28,29]. CCAMLR is based upon the conviction and understanding that the waters surrounding the Antarctic continent form a distinct marine region. Thus, there was recognition from the outset that the requirements of ecosystem management would require coverage of an area larger than that of the Antarctic Treaty. As early as 1977, the ATCPs agreed that the agreement should apply not only to the area of the Antarctic Treaty, but also should "extend north of $60^{\circ}$ South Latitude where that is necessary for the effective conservation of species of the Antarctic ecosystem" [30]. The application of the Convention extends up to the Antarctic convergence, or polar front, which is a complex transition zone lying between $45^{\circ}$ and $60^{\circ}$ south latitude, within which colder Antarctic waters sink beneath the warmer, sub-Antarctic waters to the north.

According to Article II of CCAMLR, the ecosystem approach contains three basic elements or conservation principles: the first, maximum net recruitment, requires harvesting and associated activities to prevent a decrease in the size of any harvested population to 
levels below those which ensure the population's stable recruitment; the second, maintenance of ecological relationships, requires harvesting and associated activities to prevent changes or minimize the risk of changes in the marine ecosystem; and the third requires parties to the Convention to maintain the ecological relationships that exist between harvested, dependent, and related populations of Antarctic marine living resources, and to restore depleted populations to levels which ensure the greatest net annual increment. This provision provides authorization for designating selected protected areas of the sea where harvest would be prohibited unless it would restore the ecosystem to such a structure and function as it was before harvesting occurred. The establishment of such areas in the Southern Ocean would provide a hedge against uncertainty and the risk of inadvertent exploitation in harvesting elsewhere [30].

The ecosystem standard provided in CCAMLR was viewed as an important innovation in international arrangements for marine living resource management [31]. It is designed to protect the marine ecosystem as a whole, while conserving living species. However, due to the absence of an effective enforcement mechanism and comprehensive scientific data about the whole marine ecosystem, there are many difficulties in its implementation [32]. Secondly, the term "rational use" in the conservation principle of CCAMLR is yet to be unambiguously defined, i.e., how and to what extent the use is rational. Furthermore, since the entry into force of CCAMLR, the ecosystem standard has not been effectively enforced, with particular conservation measures coming into being so late that some species and areas have been over-exploited already [33]. In this context, for the purpose of the effective implementation of the ecosystem standard of CCAMLR, it is necessary to make it clear in furtherance of the concept of sustainable development to apply the precautionary principle: the catch of the species of which mankind has collected sufficient scientific data is permissible, but fishing must be sustainable and subject to the total allowed catch which must ensure the greatest net recruitment of the taken species. As for species for which there is lack of sufficient scientific data, the catch should be strictly controlled or forbidden while awaiting further scientific justification. In short, fishing activities shall be prohibited unless they are conducted in full compliance with the ecosystem standard.

The ecosystem principle/approach is generally incorporated into the international fisheries laws, but there is still room to discuss whether it is applicable to climate change. However, it has correctly pointed out that "efforts to develop an ecosystem based approach without taking into account climate change would lead to unfortunate results" [34]. On the other hand, "climate change is a key driver for developing an ecosystem based fishery management as it exerts a pervasive influence over the whole fished system" [34].

\subsection{Principle of Common but Differentiated Responsibilities}

Article 4 of the UNFCCC specifies the treaty obligations for developed and developing countries in accordance with the principle of common but differentiated responsibilities. There is general agreement that the protection of the climate system is a common responsibility of all parties to the UNFCCC, and this common responsibility could be said to flow from the common concern occasioned by climate change and its adverse effects [15]. The common responsibility of all parties is to cooperate in developing the climate change regime, and to work to achieve the objective of the Convention by taking steps to protect the climate system for present and future generations [20].

As for the differentiated responsibilities, there is consensus that many, albeit not all, of the responsibilities of states under the climate change regime are subject to differentiation [20]. This differentiation is reflected in the distinctions between Annex I, non-Annex I, states with economies in transition, and least-developed states that are drawn in UNFCCC Article 4, as well as distinctions between Annex I and non-Annex countries in the Berlin Mandate and the Kyoto protocol, and between developed and developing countries in the Bali Action Plan [20].

Large developing countries such as China and India frequently used this principle for any climate change negotiation. For example, China presented its working paper 
on addressing aviation emissions based on the principle "common but differentiated responsibilities"' to the International Civil Aviation Organization (ICAO) in September 2007 [35] and, jointly with India, the application of the principle "common but differentiated responsibilities" to the reduction of greenhouse gas emissions from international shipping to the International Maritime Organization (IMO) in August 2008 [36]. It is opined that a treaty with limited differential treatment in favor of developing countries and considerable flexibility for all would be held up as the gold standard for the negotiation of the 2015 climate agreement [37]. According to the Paris Agreement adopted in December 2015, its implementation should reflect equity and the principle of common but differentiated responsibilities and respective capabilities in light of different national circumstances [38].

While the principle of common but differentiated responsibilities constitutes a pivotal norm in the overall legal framework for climate change, it may not directly apply to fisheries management. Though financial assistance and/or technology transfer is sometimes reflected in fishery agreements, there is no express mention of the differentiation between developing and developed countries in fisheries agreements. It would be interesting to see whether it would be applicable to fishery management in future.

Besides the above legal principles, other principles used for climate change can be used for fisheries management, such as best management practices and ecosystem-based management. The general principle of cooperation applies to both sectors. To examine the applicability of these principles in the context of climate change, a case study is observed in the following section.

\section{Existing Fisheries Agreements}

The case study is focused on the fishery agreement between China and Japan, a bilateral agreement in international law. As we know, both China and Japan border the East China Sea, where fishermen from both countries have operated since ancient times. Before the establishment of official diplomatic ties between the two countries, non-governmental fishery agreements were signed in 1955, 1963, and 1965.

Following the establishment of diplomatic ties, the two countries started their consultations on a governmental fishery agreement. The fishery agreement between the Government of the People's Republic of China and the Government of Japan was finally signed on 15 August 1975, and came into force on 23 December 1975 [39]. The 1975 Agreement was revised twice, in 1978 and in 1985 [19]. Although the 1975 agreement introduced more rigid protective measures than the non-governmental agreements, it was largely the same as the non-governmental ones.

The entry into force of the LOSC in 1994 ushered in a new era of fishery relations between China and Japan. Both countries established their EEZs based on the relevant provisions of the LOSC, as well as on their respective domestic legislations. Since the broadest width of the East China Sea is less than $400 \mathrm{~nm}$, the whole sea area became EEZs that were shared by China, Japan and Korea. The fishery relationship between the two sides inevitably needed a new adjustment. After several rounds of negotiation, the two sides finally reached agreement in September 1997 regarding fishery management in the East China Sea [40]. The new agreement came into force on 1 June 2000.

The agreement contains some significant provisions in response to the changed situation. (a) the agreement contains as one of its purposes the establishment of a new fishery order in accordance with the LOSC, conserving and utilizing rationally marine living resources of common concern, and maintaining the normal operation order at sea. Both sides agreed to cooperate to conduct scientific research in fishery and to conserve marine living resources [39]. Each should adopt necessary measures to ensure compliance by their nationals and fishing boats with the provisions of the fishery agreement and the conservation measures and other conditions provided for in the relevant laws and regulations of the other party when they are engaged in fishery activities in the other's EEZ, and should inform each other of such conservation measures and other conditions provided for in its relevant laws and regulations [39]. (b) providing reciprocal fishing rights: the agreement 
applies to the EEZs of both countries. However, this does not include all the EEZs, as the agreement excludes the EEZ area south of $27^{\circ} \mathrm{N}$, and west of $125^{\circ} 30^{\prime} \mathrm{E}$ in the East China Sea, where Taiwan and the disputed Diaoyu/Senkaku Islands are located. Within the EEZ, China and Japan give each other's nationals and fishing boats the right to fish in each other's EEZs, pursuant to the principle of reciprocity, the fishery agreement and their relevant domestic laws and regulations. The competent authorities of each party issue fishing permits to nationals and fishing boats of the other party, and may levy appropriate fees on the issuance of such permits. (c) Establishing the provisional measures zone (PMZ). For the conservation and quantity of fishery resources in the PMZ, both sides should adopt, based on decisions made by the Sino-Japanese Fishery Joint Committee, appropriate management measures in order to protect marine living resources from the harm of being overexploited. Each party should take administrative and other necessary measures for its nationals and fishing boats fishing in the PMZ, and should not impose administrative and other measures on nationals and fishing boats of the other party in this water area. The establishment of a common fishery zone is a typical form of fishery cooperation for shared waters between any two countries. Though there are many examples in the world, what is new is that the PMZ was the first such zone between China and Japan. It indicates that the fishery cooperation between these two countries had entered into a new era. (d) In order to implement the fishery agreement as well as to coordinate respective fishery management procedures, both sides decided to establish the Joint Fishery Committee which consists of four members, two of whom are appointed by each party. The decision-making mechanism is based on the unanimous consent of the committee members [39].

From the above, we can see that the latest fishery agreement between China and Japan is a positive response to the LOSC without considering any factor of climate change, and although some conservation measures provided for in the agreement are indirectly related to the climate change regime/law. A similar legal phenomenon also exists in domestic legislation in fisheries management. For example, the 1976 Magnuson-Stevens Fishery Conservation and Management Act (MSA) was amended in 1996 and 2006 with an increased conservation focus that strengthened the role that science should play in decision-making, but "no explicit mention of climate change or particular level of scientific certainty is required by the legislation" [19].

The Arctic experienced major melts in 2007 and 2012, and has seen a general trend of decline in ice thickness and extent. In 2017, Arctic ice hit a record winter low for the third year in a row. Ice-free waters, combined with the general warming trend, have brought new species to Arctic waters, e. g. the snow crab moving into Svalbard's waters [8]. The increased presence and availability of commercial species may encourage a new competitive race to fish in Arctic waters. Acknowledging the Arctic ocean systems have been changed "due to climate change and other phenomena, and that the effects of these changes are not well understood" [41], five bordering countries (Canada, Denmark [Greenland], Norway, the Russia Federation, and the United States of America) and other possible fishing countries (China, Iceland, Japan, the Republic of Korea, and the European Union) concluded the Agreement to Prevent Unregulated High Seas Fisheries in the Central Arctic Ocean, agreeing to a fishing ban for the next 16 years to give scientists time to understand the region's marine ecology and the potential impacts of climate change before fishing becomes widespread [13]. The climate change factors have been considered in the Agreement to Prevent Unregulated High Seas Fisheries in the Central Arctic Ocean maybe a positive start, but there is no specific provision directly related to climate change in this agreement.

Therefore, it is worth examining some of the latest fishery agreements to see whether the climate factor has been considered. In addition to bilateral fisheries agreements, climate change could be a necessary element in the future making of fisheries law at international, regional (North Pacific), bilateral, or even domestic levels. Towards that direction, future fishery agreements should not only apply the legal principles mentioned above, but also introduce more specific measures in response to climate change, such as reduction of 
emissions from fishing vessels; improvement of fuel efficiency; and reduction of yields and increase of yield variability.

\section{Regional and National Efforts for Climate Resilience in Fisheries}

Regional Fisheries Management Organizations (RFMOs) are international organizations that serve as fora for the establishment, implementation, and enforcement of legally binding management and conservation measures for fishing. Many RFMOs are established under international conventions and have the authority to adopt legally binding provisions with regard to the conservation and management of fish stocks. Recognizing climate change and its impacts on the environment and fishery resources, several RFMOs and many states take efforts for climate resilience in fisheries.

Environmental changes driven by climate change are further compounded by local habitat changes in salmon freshwater ecosystems. The Big Bar landslide on the Fraser river is particularly concerning, as it has blocked upstream access to critical sockeye, chinook, and coho spawning areas since 2019, and the changing ocean conditions may be further influenced by increases in salmon numbers rearing in the North Pacific [42]. The Working Group on Salmon Marking (WGSM) of the North Pacific Anadromous Fish Commission (NPAFC) developed a high-seas otolith mark recovery database that would complement the existing mark release database and provide researchers with data that could be used to assess returns across each species range, validate genetic stock identifications, establish migration patterns, infer impacts of climate change and carrying capacity, and make inferences about inter- and intra-species population dynamics [42]. Meanwhile, the member states also take action to deal with climate change in their fishery management. For example, the Korean 2020 research plan involves investigations of mortality and climate change effects on salmon to reveal the mechanisms of mass mortality of chum salmon during their early life in rivers and coastal areas in conjunction with return rate fluctuations [42]. Russia plans to conduct surveys in the northwestern Pacific Ocean, Okhotsk, and Bering Seas, and the information from surveys will be used to improve the understanding of how climate change will affect Pacific salmon production and ecosystems of the far eastern seas and adjacent Pacific waters [42].

States in the Asia-Pacific Fishery Commission (APFIC) region have made wide-ranging efforts with respect to climate change adaptation and mitigation, include climate-smart fisheries for sustainable food security, climate resistant fisheries products, climate-smart management practices. For example, Bangladesh has climate change-resilient fisheries in its development plan. Several countries, including Cambodia, Malaysia, Nepal, and the Philippines, are working to establish community-targeted early-warning and notification systems regarding climate changes [43].

It is also to note that cooperation among states is important to deal with the impact of climate change on fisheries, such as sharing data and information. In this regard, the South East Atlantic Fisheries Organization (SEAFO) has taken steps to enter into co-operation agreements with other RFMOs, such as CCAMLR, on collecting data and information that could be used to study the impact of climate change on the marine ecosystems [44].

\section{Remaining Issues}

Due to the complexity of international governance for fishery management and climate change, there are considerable pending issues to be sorted out. First is the impact of carbon storage on fisheries and how we should regulate it. Certain climate mitigation and adaptation measures may have significant impacts on the marine environment. For instance, carbon capture and storage (CCS), touted as a mitigation technology that could lead to deep emission reductions, could also if the technology is mishandled and/or mismanaged lead to significant leakage of stored $\mathrm{CO}_{2}$ occurs to the ocean [15]. Climate geo-engineering is a problem of a similar nature.

The Protocol to the Convention on the Prevention of Marine Pollution by Dumping of Wastes and Other Matter adopted in 1996 created, in a 2007 amendment, a new category 
in the Annex 1 list of wastes and other matter that may be considered for dumping, thereby allowing for the storage of $\mathrm{CO}_{2}$ in sub-seabed geological formations [15]. The parties to the 1996 Protocol adopted a "Risk Assessment and Management Framework for $\mathrm{CO}_{2}$ Sequestration in Sub-Seabed Geological Structures (CS-SSGS)" as well as "specific guidelines for assessment of carbon dioxide streams for disposal into sub-seabed geological formations." The 1992 Convention for the Protection of the Marine Environment of the North-East Atlantic (OSPAR) adopted a similar amendment to allow carbon storage in geological formations under the seabed, complemented by guidelines adopted by the OSPAR Commission [15]. It remains unknown whether these regulations are adequate, particularly in the context of the conservation of marine biological resources including fisheries, and whether the lawmakers considered the impact of such activities on fisheries.

Second, but not last, is the linkage of livelihood of the coastal communities and fisheries management in the context of climate change. It is advocated to increase the use of marine protected areas as a climate change adaptation strategy in threatened marine ecosystems [45]. This is no doubt a positive call, but such more establishments may affect fishing communities and their livelihoods. The case registered with the Permanent Court of Arbitration concerning the Matter of the Chagos Marine Protected Area between Mauritius and the United Kingdom (2010-2015) is illustrative. In the case, Mauritius challenges the United Kingdom's establishment of a Marine Protected Area (MPA) around the Chagos archipelago, which extends to a distance of 200 nautical miles from the baselines of this archipelago and covers an area of more than half a million square kilometers [46]. One of the legal challenges from Mauritius is that "the MPA is fundamentally incompatible with the rights and obligations provided for by the Convention, including the fishing rights of Mauritius in regard to the Chagos Archipelago and its surrounding waters" [46]. The above dispute shows that it is necessary to consider the needs and interests of local fishing communities while any environmental protection measure is put in place.

\section{Conclusions}

The International Bar Association, in 2014, released a detailed report on the role of international law in addressing climate change and advocates the concept of climate justice [47]. Climate justice implies the recognition that climate change is a matter of human rights and development, and also that the victims of global warming are not responsible for it [48]. Climate justice also means sharing responsibility [48]. As Mary Robinson states, "the only solution to climate change are fair solutions that protect human rights and uphold the rule of law" [48]. In terms of fishery management and the fishery legal regime, it is certainly the time for policy/law makers to accommodate the climate change considerations into the process of fishery policies and fishery laws, whether international, regional, or domestic. This paper has argued that, first, some fundamental principles of international law should be applicable to future fisheries regulation, no matter whether it is multilateral, regional, bilateral, or national; and second, that climate change factors should be seriously considered in the concluding of future fishery agreements. With this in mind, human mankind may realize climate justice for present and future generations.

Funding: It is acknowledged that this paper is part of a research project funded by China's National Social Sciences Foundation (18VHQ002).

Institutional Review Board Statement: Not applicable.

Informed Consent Statement: Not applicable.

Data Availability Statement: The data presented in this study are openly available in website, reference number.

Acknowledgments: The author expresses his gratitude to Lei Zhang for her assistance during the revising process of the paper.

Conflicts of Interest: The author declares no conflict of interest. 


\section{References}

1. Williams, L.; Rota, A. Impact of Climate Change on Fisheries and Aquaculture in the Developing World and Opportunities for Adaption. Available online: http:/ / www.ifad.org/lrkm/pub/fisheries.pdf (accessed on 23 May 2021).

2. WorldFish Center. Fisheries and Aquaculture Can Provide Solutions to Cope with Climate Change; Issues Brief No. 1701; WorldFish Center: Penang, Malaysia, 2007.

3. WorldFish Center. The Threat to Fisheries and Aquaculture from Climate Change; Policy Brief; WorldFish Center: Penang, Malaysia, 2007; p. 6.

4. IPCC. Climate Change 2014: Impacts, Adaptation, and Vulnerability. Part B: Regional Aspects; Barros, V.R., Field, C.B., Dokken, D.J., Mach, K.J., Mastrandrea, M.D., Bilir, T.E., Chatterjee, M., Ebi, K.L., Estrada, Y.O., Genova, R.C., et al., Eds.; Contribution of Working Group II to the Fifth Assessment Report of the Intergovernmental Panel on Climate Change; Cambridge University Press: Cambridge, UK; New York, NY, USA, 2014.

5. Palacios-Abrantes, J.; Sumaila, U.R.; Cheung, W.W.L. Challenges to Transboundary Fisheries Management in North America under Climate Change. Ecol. Soc. 2020. [CrossRef]

6. $\quad$ Bindoff, N.L.; Cheung, W.W.L.; Kairo, J.G.; Arístegui, J.; Guinder, V.A.; Hallberg, R.; Nathalie Jeanne Marie, H.; Nianzhi, J.; Md Saiful, K.; Lisa, L.; et al. Changing Ocean, Marine Ecosystems, and Dependent Communities. In IPCC Special Report on the Ocean and Cryosphere in a Changing Climate; Pörtner, H.-O., Roberts, D.C., Masson-Delmotte, V., Zhai, P., Tignor, M., Poloczanska, E., Mintenbeck, K., Alegría, A., Nicolai, M., Okem, A., et al., Eds.; 2019; in press; p. 456. Available online: https://www.ipcc.ch/site/assets/uploads/sites/3/2019/11/09_SROCC_Ch05_FINAL-1.pdf (accessed on 27 July 2021).

7. Nicholls, R.J.; Wong, P.P.; Burkett, V.R.; Codignotto, J.; Hay, J.; McLean, R.; Ragoonaden, S.; Woodroffe, C.D.; Abuodha, P.A.O.; Arblaster, J.; et al. Coastal Systems and Low-lying Areas. In Climate Change 2007: Impacts, Adaptation and Vulnerability; Parry, M.L., Canziani, O.F., Palutikof, J.P., van der Linden, P.J., Hanson, C.E., Eds.; Contribution of Working Group II to the Fourth Assessment Report of the Intergovernmental Panel on Climate Change; Cambridge University Press: Cambridge, UK, 2007 ; pp. 315-356. Available online: http:/ / www.ipcc.ch/pdf/assessment-report/ar4/wg2/ar4-wg2-chapter6.pdf (accessed on 24 May 2021).

8. Mendenhall, E.; Hendrix, C.; Nyman, E.; Roberts, P.M.; Hoopes, J.R.; Watson, J.R.; Lam, V.W.; Sumaila, U.R. Climate Change Increases the Risk of Fisheries Conflict. Marine Policy 2020, 117, 103954. [CrossRef]

9. FAO. Climate Change for Fisheries and Aquaculture; Technical background document from the Expert Consultation; FAO: Rome, Italy, 2008; Available online: ftp:/ / ftp.fao.org/docrep/fao/meeting/013/ai787e.pdf (accessed on 24 May 2021).

10. FAO. Fisheries and Aquaculture in a Changing Climate; Multi-Agency Brief; FAO: Rome, Italy, 2009; Available online: ftp://ftp.fao. org/FI/brochure/climate_change/policy_brief.pdf (accessed on 24 May 2021).

11. Roessig, J.M.; Woodley, C.M.; Cech, J.J.; Hansen, L.J. Effects of Global Climate Change on Marine and Estuarine Fishes and Fisheries. Rev. Fish Biol. Fish. 2004, 14, 251-275. Available online: http://www.ifad.org/lrkm/pub/fisheries.pdf (accessed on 24 May 2021). [CrossRef]

12. Lam, V.W.Y.; Allison, E.H.; Bell, J.D.; Blythe, J.; Cheung, W.W.L.; Frölicher, T.L.; Gasalla, M.A.; Sumaila, U.R. Climate Change, Tropical Fisheries and Prospects for Sustainable Development. Nat. Rev. Earth Environ. 2020, 1, 440-454. [CrossRef]

13. FAO. The State of World Fisheries and Aquaculture 2018; Food and Agriculture Organization of the United Nations: Rome, Italy, 2018.

14. FAO. The State of World Fisheries and Aquaculture 2020; Food and Agriculture Organization of the United Nations: Rome, Italy, 2020.

15. International Law Association (ILA) Washington Conference: Legal Principles Relating to Climate Change. 2014, p. 37. Available online: https:/ / papers.ssrn.com/sol3/papers.cfm?abstract_id=2461556 (accessed on 24 May 2021).

16. Boyle, A. Law of the Sea Perspectives on Climate Change. Int. J. Mar. Coast. Law 2012, 27, 831-838. [CrossRef]

17. Article 6 of the UN Fishery Stocks Agreement. Available online: http://www.un.org/depts/los/convention_agreements/texts/ fish_stocks_agreement/CONF164_37.htm (accessed on 25 May 2021).

18. ITLOS. Case No.17. 1 February 2011. p. 131. Available online: https://www.itlos.org/en/main/cases/list-of-cases/case-no-17/ (accessed on 21 June 2021).

19. McLaughlin, R.J. Responding to Climate Change to Fisheries and Marine Habitat in the Gulf of Mexico. In Climate Change Impacts on Ocean and Coastal Law: US and International Perspectives; Abate, R.S., Ed.; Oxford University Press: Oxford, UK, $2015 ;$ p. 102.

20. UNFCCC. Available online: http://unfccc.int/files/essential_background/background_publications_htmlpdf/application/ pdf/conveng.pdf (accessed on 25 May 2021).

21. World Commission on Environment and Development. Our Common Future; Oxford University Press: Oxford, UK, 1987 ; p. 43.

22. The Rio Declaration on Environment and Development. Available online: http://www.unep.org/Documents.Multilingual/ Default.asp?documentid=78\&articleid=1163 (accessed on 25 May 2021).

23. Chapter 17 of Agenda 21. Available online: http://www.unep.org/Documents.Multilingual/Default.asp?DocumentID=52 \&ArticleID=65\&l=en (accessed on 25 May 2021).

24. The Johannesburg Declaration on Sustainable Development. Available online: http://www.bnpparibas.com/en/sustainabledevelopment/text/Johannesburg-Declaration.pdf (accessed on 25 May 2021).

25. Case Concerning the Gabčíkovo-Nagymaros Project (Hungary/Slovakia). Judgement of 25 September 1997. Available online: http:/ / www.icj-cij.org/docket/ files/92/7375.pdf (accessed on 25 May 2021). 
26. Case Concerning Pulp Mills on the River Uruguay (Argentina v. Uruguay). Judgement of 20 April 2010. Available online: http:/ / www.icj-cij.org/docket/files/135/15877.pdf (accessed on 25 May 2021).

27. UN Convention on Biological Diversity. Available online: http://www.un-documents.net/cbd.htm (accessed on 27 May 2021).

28. Basson, M.; Beddington, J.R. CCAMLR: The Practical Implications of an Ecosystem Approach. In The Antarctic Treaty System in World Politics; Jorgensen-Dahl, A., Ostreng, W., Eds.; MacMillam: London, UK, 1991; p. 54.

29. Fabra, A.; Gascón, V. The Convention on the Conservation of Antarctic Marine Living Resources (CCAMLR) and the Ecosystem Approach. Int. J. Marine Coastal Law 2008, 23, 567-598. [CrossRef]

30. Scully, T.; Brown, W.; Manheim, B. The Convention for the Conservation of Antarctic Marine Living Resources: A Model for Large Marine Ecosystem Management. In Variability and Management of Large Marine Ecosystems; Sherman, K., Alexander, L.M., Eds.; Westview Press: Boulder, Colorado, 1986; p. 282.

31. Scully, T. The Convention on the Conservation of Antarctic Marine Living Resources-A Case Study. In New Developments in Marine Science and Technology: Economic, Legal and Political Aspects; Alexander, S.A., Allen, S., Hanson, L.C., Eds.; Law of the Sea Institute Proceedings: Honolulu, HI, USA, 1989; p. 138.

32. Holdgate, M.W. Antarctica: Ice Under Pressure. Environmental 1990, 32, 9. [CrossRef]

33. Vicuna, F.O. The Implementation of CCAMLR: Is the Decision-Making Machinery Conducive to Good Management? Int. Chall. $1990,10,9$.

34. Fluharty, D. Decision-Making and Action Taking: Fisheries Management in a Changing Climate; OECD Food, Agriculture and Fisheries Papers, No.36; OECD Publishing: Paris, France, 2011; p. 9.

35. A36-WP/235. 18 September 2007. Available online: https://www.icao.int/Meetings/AMC/MA/Assembly\%2036th\%20Session/ wp235_en.pdf\#search=A36\%2DWP\%2F235 (accessed on 31 May 2021).

36. MEPC 58/4/32 (15 August 2008), Cited in Agarwal, S.K. Mitigating Greenhouse Gas (GHG) Emissions from International Shipping in Post-Kyoto Climate Policy: Legal Issues and Challenges. Marit. Aff. J. Natl. Marit. Found. India 2009, 5, 73-96. Available online: https: / / www.tandfonline.com/doi/abs/10.1080/09733150903122925 (accessed on 23 August 2021). [CrossRef]

37. French, D.; Rajamani, L. Climate Change and International Environmental Law: Musings on a Journey to Somewhere. J. Environ. Law 2013, 25, 443. [CrossRef]

38. Paris Agreement. Available online: https:/ /unfccc.int/resource/docs/2015/cop21/eng/109.pdf (accessed on 31 May 2021).

39. Fishery Administrative Bureau; Ministry of Agriculture; PRC (Eds.) Sino-Japanese Governmental Fishery Agreements and NonGovernmental Protocols on the Safety of Fishing Operations; Ministry of Agriculture of PRC: Beijing, China, 1993; pp. 1-19. (In Chinese)

40. Valencia, M.J. They are concerned with the establishment of a horsepower restriction line inside which trawlers and purse seiners of $600 \mathrm{hp}$ or more are prohibited to enter; closed areas or suspension areas which are completely closed during designated peri-ods; and fishing restrictions concerning minimum body length, minimum mesh size, light intensity fish-attracting devices, incidental catch limit. In A Maritime Regime for Northeast Asia; Oxford University Press: Hong Kong, China, 1996 ; p. 258.

41. The Preamble of the Agreement to Prevent Unregulated High Seas Fisheries in the Central Arctic Ocean. Available online: https: //www.state.gov/the-agreement-to-prevent-unregulated-high-seas-fisheries-in-the-central-arctic-ocean-enters-into-force/ (accessed on 23 August 2021).

42. North Pacific Anadromous Fish Commission Annual Report 2020. Available online: https://npafc.org/wp-content/uploads/ Public-Documents /2020/AR2020.pdf (accessed on 11 August 2021).

43. Wongbusarakum, S.; De Jesus-Ayson, E.G.; Weimin, M.; DeYoung, C. Building Climate-Resilient Fisheries and Aquaculture in the Asia-Pacific Region-FAO/APFIC Regional Consultative Workshop, Bangkok, Thailand, 14-16 November 2017; FAO: Bangkok, Thailand, 2019; Available online: http:/ / www.fao.org/3/ca5770en/CA5770EN.pdf (accessed on 11 August 2021).

44. Report of the 16th Annual Meeting of the South East Atlantic Fisheries Organization. 25-28 November 2019. Available online: http:/ / www.seafo.org/Documents (accessed on 11 August 2021).

45. Craig, R.K. Ocean Governance for the 21st Century: Making Marine Zoning Climate Change Adaptable. Harvard Environ. Law Rev. 2012, 36, 305.

46. Award 18 March 2015. p. 5. Available online: http://www.pca-cpa.org/MU-UK\%2020150318\%20Awardd4b1.pdf?fil_id=2899 (accessed on 31 May 2021).

47. International Bar Association. Achieving Justice and Human Rights in an Era of Climate Disruption. International Bar Association Climate Change Justice and Human Rights Task Force Report. July 2014. Available online: https://www.ibanet.org/ MediaHandler?id=0f8cee12-ee56-4452-bf43-cfcab196cc04 (accessed on 21 June 2021).

48. Robinson, M. International Law Is Coming up Short in Its Response to Climate Change. The Guardian, 9 January 2015. Available online: http:/ / www.theguardian.com/sustainable-business/2015/jan/09/mary-robinson-law-coming-up-short-climate-change (accessed on 31 May 2021). 